\title{
OPEN Vicilin and legumin storage proteins are abundant in water and alkali soluble protein fractions of glandless cottonseed
}

\begin{abstract}
Zhongqi He ${ }^{1 凶}$, Christopher P. Mattison ${ }^{1}$, Dunhua Zhang ${ }^{2}$ \& Casey C. Grimm ${ }^{1}$
In this work, we sequentially extracted water (CSPw)- and alkali (CSPa)-soluble protein fractions from glandless cottonseed. SDS-Gel electrophoresis separated CSPw and CSPa to 8 and 14 dominant polypeptide bands (110-10 kDa), respectively. Liquid chromatography-electrospray ionizationtandem mass spectrometry identified peptide fragments from 336 proteins. While the majority of peptides were identified as belonging to vicilin and legumin storage proteins, peptides from other functional and uncharacterized proteins were also detected. Based on the types (unique peptide count) and relative abundance (normalized total ion current) of the polypeptides detected by mass spectrometry, we found lower levels (abundance) and types of legumin isoforms, but higher levels and more fragments of vicilin-like antimicrobial peptides in glandless samples, compared to glanded samples. Differences in peptide fragment patterns of $2 \mathrm{~S}$ albumin and oleosin were also observed between glandless and glanded protein samples. These differences might be due to the higher extraction recovery of proteins from glandless cottonseed as proteins from glanded cottonseed tend to be associated with gossypol, reducing extraction efficiency. This work enriches the fundamental knowledge of glandless cottonseed protein composition. For practical considerations, this peptide information will be helpful to allow better understanding of the functional and physicochemical properties of glandless cottonseed protein, and improving the potential for food or feed applications.
\end{abstract}

With about $28 \times 10^{9} \mathrm{~kg}$ or 124 million bales of cotton produced annually, cotton plant (Gossypium hirsutum L.) is an economically important crop known for fiber, cottonseed oil, and protein contents ${ }^{1-3}$. Currently, cotton fiber and cottonseed account for $85-90 \%$ and $10-15 \%$ of the value of the crop, respectively, while $150 \mathrm{~kg}$ of cottonseed is produced for every $100 \mathrm{~kg}$ fiber ginned. The cottonseed consists of approximately $16 \%$ oil, $45 \%$ meal, $25 \%$ hull, and $8 \%$ linters. The major components of defatted meal are carbohydrates and protein. Cottonseed protein comprises multiple polypeptides (i.e., various protein fractions) including seed storage proteins and proteins with other biological functions ${ }^{4,5}$. Cottonseed protein has great potential as a component of value-added industrial products and bio-active functional materials. The potential added-value products of cottonseed protein isolates include, but are not limited to, bio-based adhesives ${ }^{6-10}$, bioplastics and films ${ }^{11,12}$, antioxidant fractions/ peptides $^{13,14}$, and antibiotic peptides ${ }^{15}$.

The traditional variety of cottonseed contains the toxic terpenoid gossypol and is labeled "glanded cottonseed" as gossypol is deposited in scattered tissue structures called glands. Research efforts have been made to produce a new type of "glandless" cottonseed in which there is only trace gossypol content. Gossypol is a terpenoid produced and stored in the pigment glands of the typical cotton plant (about 1 weight percent (wt\%) of dry matter of cottonseed $)^{16}$. Thus, the traditional variety of cottonseed is also labeled as "glanded" cottonseed ${ }^{17,18}$. The presence of toxic gossypol limits cottonseed to mainly non-food applications ${ }^{1}$. Research has been directed towards eliminating or reducing gossypol from cottonseed (i. e., below $450 \mathrm{ppm}$ free gossypol) to mitigate the toxic effects of gossypol. One notable genetically modified cultivar, TAM66274, has ultra-low gossypol cottonseed ${ }^{16}$. Another interesting genetically engineered cultivar is NuMex COT 15 GLS' Glandless Cotton ${ }^{17}$. Cheng et al. ${ }^{19,20}$ demonstrated that the glandless cottonseed protein isolates could serve as wood adhesives. He et al. ${ }^{21}$ reported that glandless cottonseed protein-based adhesives had similar bonding performances as the glanded counterpart. In the latest study, $\mathrm{He}$ et al. ${ }^{14}$ comparatively examined the antioxidant activities of the water-soluble fractions of

${ }^{1}$ USDA-ARS, Southern Regional Research Center, New Orleans, LA 70124, USA. ${ }^{2}$ USDA-ARS, Aquatic Animal Health Research Unit, Auburn, AL 36832, USA. ${ }^{\circledR}$ email: zhongqi.he@usda.gov 


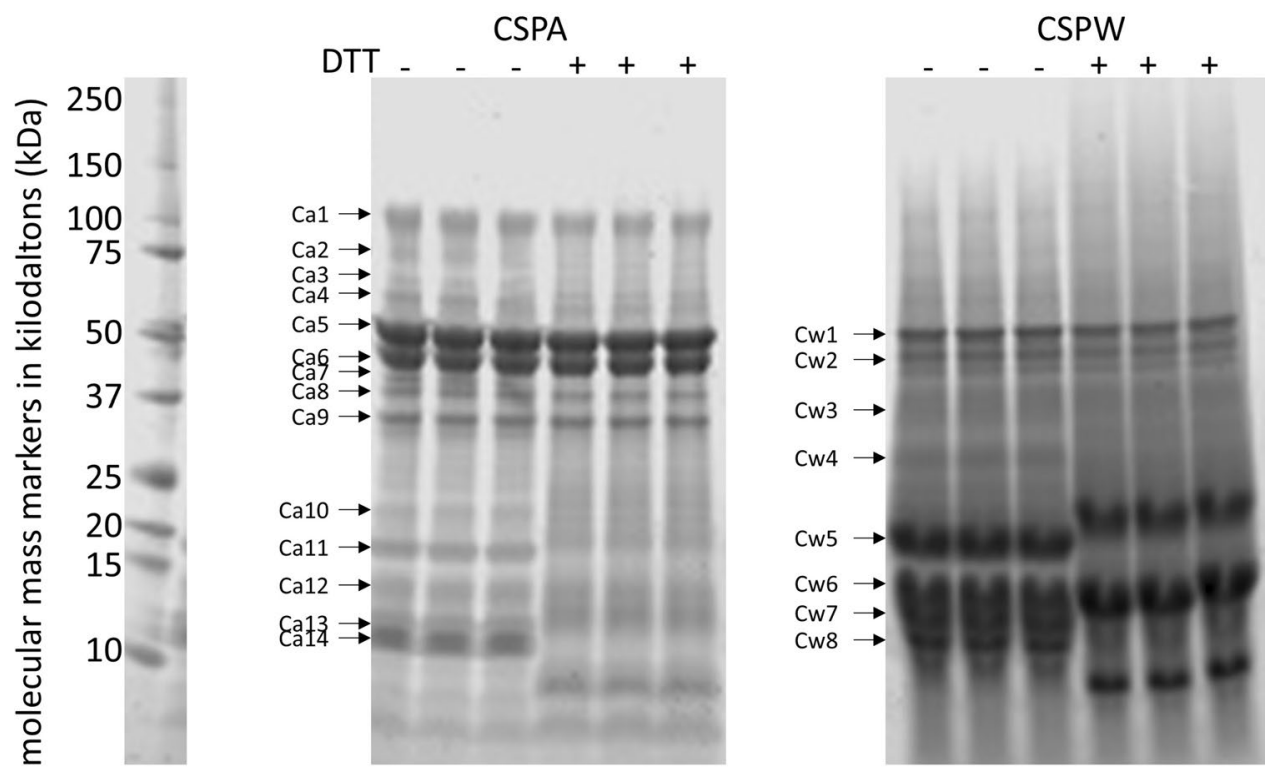

Figure 1. Gradient (10-20\% Tricine) SDS-PAGE of water- (CSPw) and alkali- (CSPa) soluble cottonseed protein isolates with $(+)$ or without $(-)$ dithiothreitol (DTT) treatment. Approximately $2 \mu \mathrm{g}$ of protein were applied to each lane. Gels were visualized and protein band intensities were quantified using the $680 \mathrm{~nm}$ channel on a Li-Cor Odyssey infrared scanner and Image Studio software (LI-COR Biosciences, USA). The SDS-PAGE profile of corresponding glanded samples can be found in $\mathrm{He}$ et al. ${ }^{4}$.

both glandless and glanded cottonseed protein. Cao et al. ${ }^{18,22}$ reported ethanol extracts from both glanded and glandless cottonseed kernels contained some bioactive ingredients.

Continued characterization of glandless cottonseed will enable improved understanding and food and feed utilization of glandless cottonseed protein. In this work, we isolated and separated glandless cottonseed proteins into water- and alkali-soluble fractions, analyzed their polypeptide profiles, and compared them to the peptide features of glanded cottonseed protein fractions.

\section{Results and discussion}

Polypeptide band features of glandless CSPw and CSPa on gradient SDS-PAGE. SDS-gel electrophoresis separated CSPw and CSPa into 8 and 14 discernable polypeptide bands, respectively (Fig. 1, fulllength gels and blots are included in a Supplementary Information file). The polypeptide bands ranged from over 100 to about $11 \mathrm{kDa}$ with CSPa, but just over 50 to $10 \mathrm{kDa}$ for CSPw. Among the $14 \mathrm{CSPa}$ bands, Ca 5 and Ca 6 at 55 and $45 \mathrm{kDa}$ were most abundant. Together, they accounted for $43 \%$ of the relative abundance of the total protein load (Fig. 2). In contrast, the three most abundant bands in the CSPw sample (Cw 5, 6 and 7) were about 20,15 and $13 \mathrm{kDa}$. Together, they accounted for $45 \%$ of the relative abundance of the total CSPw protein load. These observations were generally consistent with previous data of glandless cottonseed proteins ${ }^{14,23}$.

Similar protein band patterns with minor differences were observed when comparing glandless to glanded protein extract. There were more CSPa bands, but less CSPw bands in the glandless sample when compared to a glanded sample with $7 \mathrm{CSPa}$ and $12 \mathrm{CSPw}$ bands ${ }^{4}$. The main difference in the glandless CSPa bands was the four molecular weight bands from 60 to $110 \mathrm{kDa}$ (Ca 1 to 4) which were not observed in either the glanded CSPa fraction $^{4,24}$ or in glanded whole cottonseed protein isolates ${ }^{5,24,25}$. The presence of gossypol could result in modified SDS-PAGE protein patterns due to the chemical reactivity of gossypol with proteins. Gossypol is known to react with the free $\varepsilon$-amino group of lysine ${ }^{26}$, likely promoting the formation of protein aggregates that were more difficult to extract. In fact, protein yield was 2.5 -fold greater from the glandless meal than that from the glanded meal ${ }^{27}$. The higher extraction efficiency not only increased the quantity of protein biomass, but likely increased the diversity of observed proteins.

The glandless CSPa and CSPw extracts were also resolved on SDS-PAGE with the reducing agent dithiothreitol (DTT) to identify proteins containing disulfide bonds (Fig. 1). The CSPa extract band pattern was clearly altered by the inclusion of DTT in the loading buffer. The migration of several lower molecular weight bands (e. g., Ca10, 11, 13, and 14) in the CSPa sample appeared to be altered by DTT. While none of the relatively higher molecular weight bands in CSPw around $50 \mathrm{kDa}$ appeared to change following the addition of DTT, the migration of several lower molecular weight bands (e. g., Cw 4, 5, 7 and 8) in the CSPw fraction were altered. With the DTT treatment, the relative abundance of new bands appearing in the range of 9-15 $\mathrm{kDa}$ made up $18 \%$ and $23 \%$ of relative protein abundance, respectively, for CSPa and CSPw (Fig. 2). Ma et al. ${ }^{25}$ reported that, in the presence of the reducing agent $\beta$-mercaptoethanol, many additional minor bands appeared between 14 and $35 \mathrm{kDa}$, compared to SDS-PAGE of their glanded cottonseed protein samples in the absence of a reducing agent. The emergence of these minor bands under reducing condition suggests the presence of intermolecular 

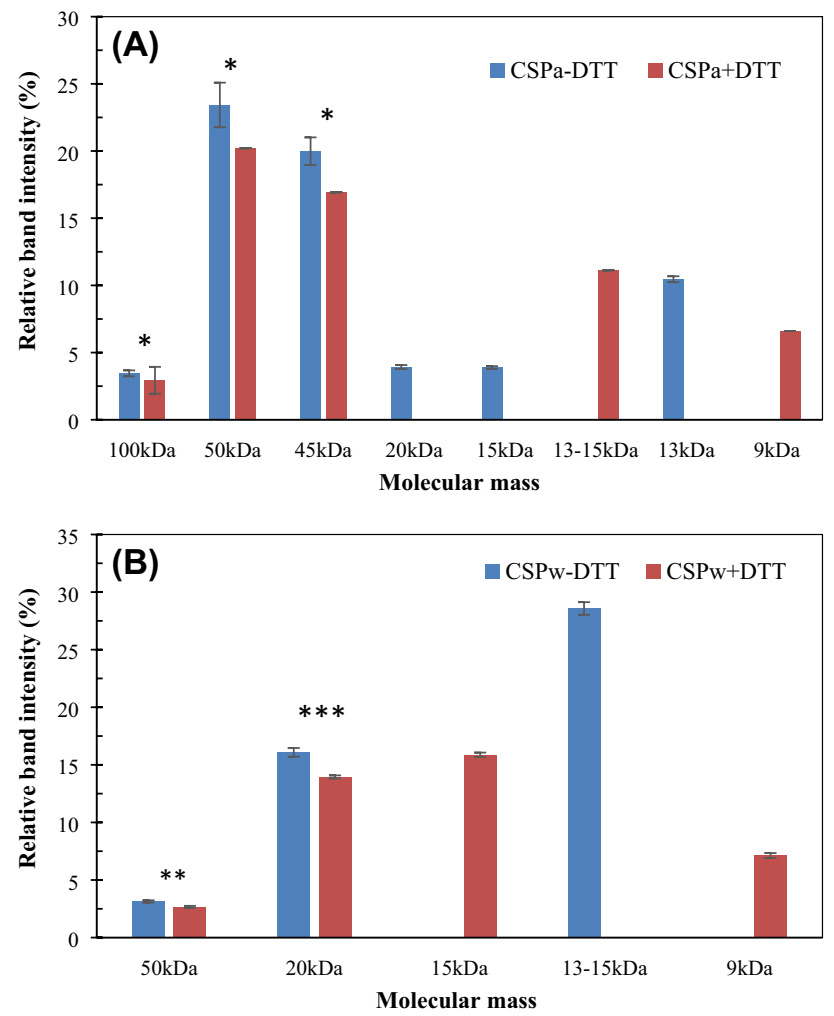

Figure 2. Relative protein band intensities as a percentage of total load with (+) or without (-) dithiothreitol (DTT) treatment. (A) Water-soluble cottonseed protein (CSPw); (B) alkali-soluble cottonseed protein (CSPa). Data are presented as average \pm standard deviation $(n=3)$. Symbol ${ }^{\star},{ }^{* *}$, and ${ }^{\star * *}$ indicate the band intensity with the same molecular weights between the two treatments significantly different at $p=0.05,0.01$, and 0.001 , respectively.

disulfide bonds in cottonseed protein isolates. It is hard to distinguish the 58/59 kDa DTT sensitive bands in the gel in Fig. 1. We are not aware of any previous research on the relevant SDS-PAGE band patterns under reducing conditions for glandless cottonseed protein samples. Like our work, Delgado et al. ${ }^{23}$ presented the SDS-PAGE of water-, $0.5 \mathrm{M} \mathrm{NaCl}$-, $70 \%$ ethanol-, and $0.1 \mathrm{NaOH}$-soluble fractions of glandless cottonseed protein without reducing agent treatment. More research is needed to find out if the less impact of reducing treatment on $58 / 59 \mathrm{kDa}$ bands is due to much less disulfide-bonded proteins presented in the glandless samples, or some other causes.

Peptide and protein profiles of CSPw and CSPa. The unique peptide count and their quantitative values are listed in spreadsheet SupTable1A and SupTable1B of the Supplementary Dataset File, respectively. In contrast to 2319 unique peptides and 70 proteins identified in the glanded sample ${ }^{4}$, there was a total of 5115 unique peptides that were matched to 336 proteins in the glandless extract. Therefore, the peptide diversity is wider for the glandless extracted than that for the glanded samples. The differences in observed peptide content provide support, but do not conclusively prove, the idea that extraction of proteins from glandless meal was more efficient than from the glanded meal ${ }^{27}$.

The molecular weight of proteins in the glandless cottonseed extracts ranged from 13 to $289 \mathrm{kDa}$, and several individual bands were compared to gene products or putative gene products of Gossypium arboretum, G. hirsutum or unspecified Gossypium species via UniPro (https://www.uniprot.org/uniprot/) and/or Conserved Domains in NCBI-BLASTp (https://blast.ncbi.nlm.nih.gov/Blast.cgi). Among them, 156 proteins appeared exclusively in CSPw bands, but only 19 proteins appeared exclusively in CSPa bands. There were 85 protein polypeptides that appeared only once in a unique CSPw band, and 22 proteins that appeared in all 8 CSPw bands. On the other hand, there were 78 protein polypeptides appearing uniquely in a single CSPa band, but 6 protein polypeptides that appeared in all 14 CSPw bands.

These proteins were functionally classified into 11 categories as protein storage, transporters, signal transduction, cell structure, transcription, translation, protein biosynthesis, protein metabolism, energy metabolism, antimicrobial activity, defense/stress, carbohydrate metabolism, fatty acid metabolism and protein species of unknown functions (Fig. 3). Biosynthesis/modification (17.4\%), translation regulation (11.7\%), transcription regulation $(12.8 \%)$ and energy metabolism $(17.1 \%)$ categories accounted for more than half of the proteins identified.

Peptides from the top 10 proteins accounted for about $25-53 \%$ of the protein biomass of a glandless CSPw band, and this was much lower than the percentages (84-100\%) of any glanded CSPw band (Tables 1 and 2). This difference indicated a more diverse protein composition in glandless CSPw than in glanded CSPw. The 


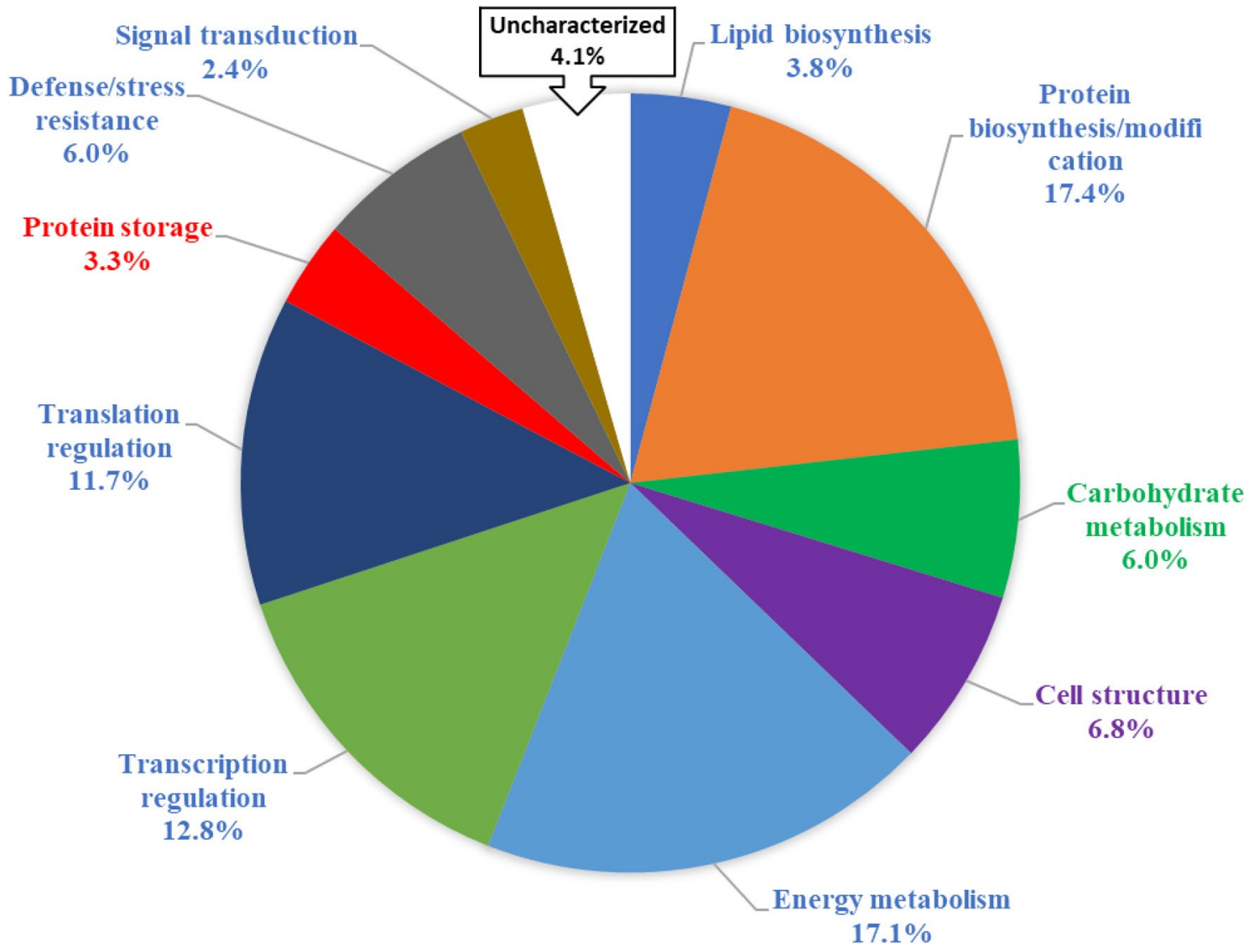

Figure 3. Biological functions and percentage of each class of proteins identified in glandless cottonseed predicted in accordance with Gene Ontology terms.

percentages of the top 10 protein in glandless CSPa bands were generally high (>90\%), except that Ca12 (50.5\%) and Ca14 (59\%) were comparable to those in glanded CSPa bands. Vicilin proteins accounted for approximately $80 \%$ of glandless CSPa proteins including Ca12 (41.11\%) and Ca14 (50.22\%). Between the two, the abundance of vicilin-like antimicrobial peptides ${ }^{28}$ was higher in CSPa $(4.52-12.93 \%)$ than in CSPw (2.65-6.36\%). Legumins (2.39-12.45\%) were the second most abundant proteins appeared in all 14 glandless CSPa bands, but not in top 10 of glandless CSPw. Indeed, legumin A and B accounted for only $0-0.88 \%$ and $0-1.9 \%$ of abundance, respectively, in glandless CSPw proteins which found in 7 and 6 of 8 CSPw bands, respectively. This observation was different from that of glanded CSPw fraction in which legumin A and B were the $1^{\text {st }}$ and $4^{\text {th }}$ most abundant, with a combined $22-53 \%$ of protein biomass (Table $1 \mathrm{~A}$ ).

The cotton 2S albumin was also observed in both CSPw and CSPa fractions of glandless cottonseed protein, but was not in the top 10 list of the glanded CSPa fraction. In contrast, another storage protein, the late embryogenesis abundant protein D-19, appeared in glanded CSPa sample. The lipid bodies-related storage protein oleosin with molecular weights of 16.4 and $18.2 \mathrm{kDa}$ was also found in both CSPw and CSPa fractions, but with lower abundances than other storage proteins and was not in the top 10 for either cottonseed sample.

Peptides from three proteins of known function (cytosolic phosphoglycerate kinase, embryonic DC-8, annexin D2-like protein) and two proteins of known function (asparticase and 60S ribosomal L10a-1-like protein) were found in the top 10 of glandless CSPw and CSPa, respectively. Interestingly, none of them were found in the 90 proteins identified in glanded cottonseed samples. Similarly, two proteins of known function appeared in CSPw (transcription initiation factor TFIID subunit 1-B-like protein, and protein lin-54) and were not found in the total list of 336 proteins of glandless cottonseed. However, two (heat shock protein 70, and elongation factor 1-alpha) of the three functional proteins in the top 10 of glanded CSPa, were observed, but were not in the top 10, in the 336 proteins of glandless cottonseed.

Comparison of peptide fragments of legumins in glandless and glanded proteins. Peptide fragments of legumin storage proteins were identified in multiple bands in both CSPw and CSPa from glandless and glanded cottonseed, and were further analyzed to compare the number of observed peptides in each band (Fig. 4). The molecular weight of legumin A is approximately $58 \mathrm{kDa}$. While legumin A peptides were identified in all glandless CSPa bands from 100 to $9 \mathrm{kDa}$, the percentage of sequence coverage and number of peptide fragments were generally higher in high molecular weight gel bands than in low molecular CSPa bands. This observation indicated that legumin A of glandless cottonseed was mainly present in CSPa bands as whole protein, multiple and/or long peptide fragments. In contrast, there were just 1, 2 or 3 peptide fragments appearing in 


\begin{tabular}{|c|c|c|c|c|c|c|c|c|c|c|c|c|c|}
\hline & MW, kDa & Cw1 & Cw2 & Cw3 & Cw4 & Cw5 & Cw6 & Cw7 & Cw8 & & & & \\
\hline \multicolumn{14}{|l|}{ (A) Glandless cottonseed } \\
\hline Vicilin C72 (G. hirsutum) & 70 & 14.11 & 12.48 & 5.88 & 7.40 & 19.82 & 12.96 & 24.67 & 14.46 & & & & \\
\hline Vicilin GC72-A & 71 & 10.17 & 14.27 & 5.79 & 5.72 & 4.07 & 23.91 & 15.42 & 10.58 & & & & \\
\hline Vicilin C72 (G. arboretum) & 70 & 12.24 & 11.44 & 5.41 & 0.00 & 0.00 & 0.00 & 0.00 & 0.00 & & & & \\
\hline Vicilin-like antimicrobial peptides $2-1$ & 62 & 2.90 & 2.84 & 3.70 & 1.78 & 2.54 & 3.54 & 2.64 & 1.76 & & & & \\
\hline Phosphoglycerate kinase, cytosolic & 42 & 1.56 & 1.61 & 1.33 & 1.68 & 3.94 & 1.52 & 1.76 & 2.47 & & & & \\
\hline Protein disulfide-isomerase \# & 56 & 1.04 & 1.13 & 1.33 & 2.07 & 2.80 & 2.36 & 1.91 & 2.65 & & & & \\
\hline Vicilin-like antimicrobial peptides $2-2$ & 55 & 1.14 & 2.08 & 2.66 & 2.27 & 1.14 & 0.51 & 1.17 & 0.88 & & & & \\
\hline $2 \mathrm{~S}$ albumin storage protein & 16 & 0.52 & 0.38 & 0.57 & 1.78 & 0.51 & 1.35 & 3.23 & 2.65 & & & & \\
\hline Embryonic DC-8 \# & 63 & 0.73 & 1.32 & 1.42 & 1.48 & 0.64 & 2.02 & 1.91 & 1.41 & & & & \\
\hline Annexin D2-like protein \# & 36 & 1.66 & 1.23 & 4.08 & 0.79 & 1.52 & 0.00 & 0.15 & 1.06 & & & & \\
\hline \multirow[t]{2}{*}{ Top 10 total } & & 46.06 & 48.77 & 32.16 & 24.95 & 36.98 & 48.15 & 52.86 & 37.92 & & & & \\
\hline & MW, kDa & Cw1 & Cw2 & Cw3 & Cw4 & Cw5 & Cw6 & Cw7 & Cw8 & Cw9 & Cw10 & Cw11 & Cw12 \\
\hline \multicolumn{14}{|l|}{ (B) Glanded cottonseed ${ }^{4}$} \\
\hline Legumin A & 58 & 13.39 & 20.29 & 21.32 & 24.80 & 26.55 & 33.93 & 23.62 & 22.88 & 23.26 & 23.14 & 32.20 & 31.08 \\
\hline Vicilin C72 (G. hirsutum) & 70 & 30.71 & 23.91 & 27.94 & 23.20 & 17.70 & 20.54 & 25.20 & 26.27 & 22.48 & 24.79 & 23.73 & 21.62 \\
\hline Vicilin GC72-A & 71 & 18.90 & 20.29 & 17.65 & 20.00 & 22.12 & 19.64 & 21.26 & 20.34 & 20.16 & 20.66 & 18.64 & 24.32 \\
\hline Legumin B & 59 & 8.66 & 10.87 & 16.18 & 19.20 & 18.58 & 18.75 & 18.11 & 18.64 & 17.83 & 22.31 & 16.95 & 21.62 \\
\hline Vicilin-like antimicrobial peptides $2-1$ & 62 & 6.30 & 5.80 & 11.03 & 4.80 & 7.96 & 1.79 & 4.72 & 5.08 & 2.33 & 3.31 & 5.08 & 0.00 \\
\hline Vicilin C72 (G. arboretum) & 70 & 5.51 & 2.90 & 2.94 & 0.80 & 1.77 & 2.68 & 1.57 & 0.00 & 1.55 & 0.83 & 0.85 & 0.00 \\
\hline $2 \mathrm{~S}$ albumin storage protein & 16 & 0.00 & 0.00 & 0.74 & 0.80 & 0.00 & 0.00 & 0.00 & 2.54 & 0.00 & 0.00 & 0.00 & 1.35 \\
\hline $\begin{array}{l}\text { Transcription initiation factor TFIID subunit 1-B-like } \\
\text { protein \# }\end{array}$ & 111 & 0.00 & 2.17 & 0.00 & 0.00 & 0.88 & 0.00 & 0.00 & 0.00 & 0.78 & 0.83 & 0.00 & 0.00 \\
\hline Protein lin-54 & 82 & 0.79 & 0.72 & 1.47 & 0.00 & 0.00 & 0.00 & 0.00 & 0.00 & 0.78 & 0.00 & 0.00 & 0.00 \\
\hline Vicilin-like antimicrobial peptides $2-2$ & 55 & 0.00 & 0.00 & 0.00 & 0.80 & 0.00 & 0.89 & 0.79 & 0.00 & 0.78 & 0.83 & 0.00 & 0.00 \\
\hline Top 10 total & & 84.25 & 86.96 & 99.26 & 94.40 & 95.58 & 98.21 & 95.28 & 95.76 & 89.92 & 96.69 & 97.46 & 100.0 \\
\hline
\end{tabular}

Table 1. Top 10 proteins of CSPw per quantitative values (\% of normalized total spectral strength of each band sample). Italics: \# Not found in glanded protein; Bold: \# not found in glandless protein.

7 of the 8 CSPw bands, suggesting degraded legumin A peptides were present in the CSPw fraction of glandless cottonseed protein. The distribution pattern of legumin B (approximately $59 \mathrm{kDa}$ ) was similar to that of legumin A. However, the number of peptide fragments and percent of sequence coverage of legumin $B$ were lower than legumin A in glandless cottonseed. In contrast, peptides of both legumin A and B from glanded cottonseed were distributed in both CSPw and CSPa bands with similar patterns. The high sequence coverage suggested the two legumins were present as whole proteins or nearly full-length polypeptides in the CSPa and CSPw fractions of glanded cottonseed proteins.

Multiple bands from a single protein could be due to three mechanisms: (1) degradation during protein isolation and post treatment, (2) contamination from gels, and (3) indigenous isoforms (including post-translational protein modification $)^{4}$. While the first and second mechanisms are possible, the systematic difference in the sequence coverage patterns observed between glandless and glanded cottonseed protein suggested the presence of isoforms. In the investigation of genomically biased accumulation of seed storage proteins in allopolyploid cotton, $\mathrm{Hu}$ et al. ${ }^{29}$ proposed that legumin isoforms may be formed through a series of modifications, including proteolytic cleavage and peptide degradation. Specifically, they found 83 spots as legumin A, and 27 spots as legumin B out of 155 identified in a 2-D SDS-PAGE image of cottonseed protein. Isoform analysis through peptide mapping indicated that the $30-\mathrm{kDa}$ polypeptide of legumin A derived from the C-terminal fragment of the $58 \mathrm{kDa}$ pre-propolypeptide. Legumin isoforms are commonly distributed at molecular mass of $30 \mathrm{kDa}, 17-20 \mathrm{kDa}$, and 11-12 $\mathrm{kDa}$ as legumin $\mathrm{A}$ and at molecular weights of $11-13 \mathrm{kDa}$ as legumin $\mathrm{B}$. Therefore, the differences in legumins between glandless and glanded cottonseed proteins may indicate that lower levels (abundance) and/or types of legumin isoforms were present in glandless cottonseed. It remains to be determined if legumin protein expression could be impacted or not by the genetic engineering of the glandless Upland cotton (G. hirsutum L.) cultivar, which carried the incomplete dominant glandless $G l 2^{e}$ allele introduced from G. barbadense ${ }^{17}$.

Comparison of vicilin peptide fragments in glandless and glanded proteins. Like legumins, vicilins are primary storage proteins of cottonseed with multiple types and isoforms ${ }^{29,30}$. Similar to glanded samples, five types of vicilin proteins were identified in glandless cottonseed protein with a wide range of molecular weights (100-9 kDa). Two vicilin-like antimicrobial peptides possess potential antifungal activity in plant development in cropping management and function against important yeasts in medical mycology for medical application ${ }^{31,32}$. The distribution of these peptides in glandless and glanded cottonseed proteins was compared (Fig. 5). No apparent difference in peptide sequence or protein coverage pattern was observed between glandless and glanded vicilin proteins. However, in contrast to legumins, both vicilin-like antimicrobial peptides $2-1$ and 


\begin{tabular}{|c|c|c|c|c|c|c|c|c|c|c|c|c|c|c|c|}
\hline & MW, kDa & Cal & $\mathrm{Ca} 2$ & $\mathrm{Ca} 3$ & $\mathrm{Ca} 4$ & $\mathrm{Ca} 5$ & Ca6 & Ca7 & Ca8 & Ca9 & Ca10 & Ca11 & Ca12 & Ca13 & Ca14 \\
\hline \multicolumn{16}{|l|}{ (A) Glandless cottonseed } \\
\hline Vicilin GC72-A & 71 & 32.78 & 33.77 & 31.51 & 30.76 & 19.19 & 36.94 & 32.16 & 23.68 & 31.92 & 27.31 & 22.37 & 15.98 & 36.26 & 18.83 \\
\hline Vicilin C72 (G. hirsutum) & 70 & 26.01 & 21.71 & 21.89 & 24.49 & 38.38 & 22.72 & 23.28 & 25.64 & 24.53 & 28.88 & 31.18 & 17.77 & 20.88 & 27.95 \\
\hline Vicilin C72 & 70 & 23.26 & 20.22 & 20.38 & 21.55 & 31.98 & 22.72 & 22.45 & 25.64 & 24.21 & 22.59 & 29.46 & 0.00 & 19.12 & 0.00 \\
\hline Legumin A & 58 & 6.59 & 8.53 & 8.49 & 7.18 & 2.65 & 6.34 & 7.37 & 5.09 & 5.35 & 3.73 & 3.44 & 2.33 & 7.91 & 1.64 \\
\hline Vicilin-like antimicrobial peptides $2-1$ & 62 & 3.85 & 4.82 & 5.09 & 4.05 & 2.96 & 4.79 & 3.35 & 7.63 & 3.62 & 2.16 & 2.58 & 5.03 & 3.96 & 2.54 \\
\hline Legumin B & 59 & 2.38 & 2.78 & 3.96 & 4.24 & 0.78 & 1.70 & 3.35 & 2.35 & 4.09 & 3.73 & 3.23 & 3.05 & 1.32 & 0.75 \\
\hline $2 \mathrm{~S}$ albumin storage protein & 16 & 0.18 & 1.11 & 0.94 & 2.76 & 0.78 & 0.31 & 1.68 & 0.59 & 0.47 & 3.73 & 0.65 & 2.51 & 4.40 & 5.68 \\
\hline Vicilin-like antimicrobial peptides $2-2$ & 55 & 0.37 & 1.11 & 0.94 & 0.55 & 0.00 & 0.00 & 0.50 & 0.78 & 0.16 & 0.59 & 0.22 & 2.33 & 0.22 & 0.90 \\
\hline Asparticase\# & 60 & 0.37 & 0.00 & 0.00 & 0.37 & 0.47 & 1.08 & 0.34 & 0.20 & 0.31 & 0.00 & 0.43 & 1.26 & 0.00 & 0.30 \\
\hline 60 ribosomal L10a-1-like protein\# & 25 & 0.55 & 0.93 & 0.57 & 0.55 & 0.00 & 0.00 & 0.67 & 0.59 & 0.31 & 0.00 & 0.43 & 0.18 & 0.00 & 0.00 \\
\hline \multirow[t]{2}{*}{ Top 10 total } & & 96.34 & 94.99 & 93.77 & 96.50 & 97.19 & 96.60 & 95.14 & 92.17 & 94.97 & 92.73 & 93.98 & 50.45 & 94.07 & 58.59 \\
\hline & MW, kDa & Ca1 & $\mathrm{Ca} 2$ & Ca3 & Ca4 & $\mathrm{Ca} 5$ & Ca6 & Ca7 & & & & & & & \\
\hline \multicolumn{16}{|l|}{ (B) Glanded cottonseed ${ }^{4}$} \\
\hline Vicilin C72 (G. hirsutum) & 70 & 35.56 & 18.12 & 14.58 & 14.76 & 26.78 & 20.32 & 25.28 & & & & & & & \\
\hline Vicilin C72 (G. arboretum) & 70 & 39.87 & 18.49 & 13.54 & 14.51 & 23.45 & 20.55 & 22.68 & & & & & & & \\
\hline Vicilin GC72-A & 71 & 15.09 & 45.78 & 15.48 & 10.91 & 11.35 & 25.64 & 10.60 & & & & & & & \\
\hline Legumin A & 58 & 2.80 & 8.56 & 38.39 & 26.70 & 11.80 & 15.94 & 27.51 & & & & & & & \\
\hline Legumin B & 59 & 2.48 & 2.73 & 6.40 & 29.40 & 18.61 & 8.55 & 5.95 & & & & & & & \\
\hline Vicilin-like antimicrobial peptides $2-1$ & 62 & 1.08 & 1.86 & 3.42 & 0.26 & 1.06 & 1.39 & 2.04 & & & & & & & \\
\hline Late embryogenesis abundant protein D-19 & 11 & 0.22 & 0.00 & 0.89 & 0.64 & 0.61 & 0.69 & 0.93 & & & & & & & \\
\hline ATP synthase subunit beta \# & 60 & 0.43 & 0.25 & 0.74 & 0.13 & 0.76 & 0.46 & 0.37 & & & & & & & \\
\hline Heat shock protein 70 & 71 & 0.00 & 0.12 & 1.04 & 0.00 & 1.06 & 0.00 & 0.37 & & & & & & & \\
\hline Elongation factor 1-alpha & 49 & 0.65 & 0.25 & 0.60 & 0.13 & 0.00 & 0.23 & 0.56 & & & & & & & \\
\hline Top 10 total & & 98.17 & 96.16 & 95.09 & 97.44 & 95.46 & 93.77 & 96.28 & & & & & & & \\
\hline
\end{tabular}

Table 2. Top 10 proteins of CSPa per quantitative values (\% of normalized total spectral strength of each band sample). Italics: \# Not found in glanded protein; Bold: \# not found in glandless protein.

2-2 seemed more abundant in glandless samples than in the corresponding glanded CSPa and CSPw samples. As the glandless cotton cultivar is depleted in gossypol in cottonseed, the increasing level of vicilin-like antimicrobial peptides may be a compensation mechanism to offset the beneficial role of gossypol's antimicrobial properties during germination and young plantlet development of the glandless $\operatorname{cotton}^{32,33}$.

Compared to the distribution of antimicrobial peptide 2-2 fragments, more antimicrobial 2-1 peptides were identified in SDS-PAGE bands in both glandless and glanded cottonseed proteins. Interestingly, the peptide 2-1 fragments were concentrated in the C-terminus, but more SDS-PAGE bands were observed to contain N-terminal fragments in vicilin-like antimicrobial peptide 2-2. Chung et al. ${ }^{34}$ separated cottonseed protein into four major cotton seed basic protein fractions by a series of chromatographic procedures, and tested their in vitro antifungal activity. They suggested that those small molecular weight cysteine-rich vicilin-like peptides (approximately $16-20 \mathrm{kDa}$ ) with in vitro antifungal activity were from an approximately $70 \mathrm{kDa}$ pre-proprotein. Furthermore, those vicilin-like antibacterial proteins $(9-11 \mathrm{kDa})$ corresponded to $\mathrm{N}$-terminally truncated forms of cysteinerich small vicilin proteins (e.g., the $16.3 \mathrm{kDa}$ protein). Their work seems consistent with our observation of the presence of both C-terminal and N-terminal enriched peptide 2-1 and 2-2. Hu et al. ${ }^{29}$ found that small isoforms of vicilin A $(49,35,11$, and $17 \mathrm{kDa})$ and vicilin $\mathrm{B}(49$ and $17 \mathrm{kDa})$ were derived from the $70 \mathrm{kDa}$ vicilin A and vicilin $B$ pre-propolypeptides through the cleavage of signal peptides together with the $\mathrm{N}$-terminal fragments, respectively, and further proposed that protein modifications (e.g., glycosylation, phosphorylation, acetylation, and methylation) likely contributed to the formation of these vicilin isoforms. Thus, there is rational and physiological justification for increased antimicrobial vicilin-like peptide production through post-translational cleavage of vicilin preprotein from glandless cotton (lacking in gossypol). The increased relative amount of antimicrobial proteins regarding glandless cottonseed protein samples would enhance its value in post-harvest products such as nutrient foods, food additives, and animal feed with better shelf life $\mathrm{e}^{14,23,35,36}$ although the antimicrobial effect in the processed industrial products needs to be further confirmed.

Comparison of peptide fragments of $2 \mathrm{~S}$ albumin and oleosin in glandless and glanded protein. Both $2 \mathrm{~S}$ albumin and oleosin are storage proteins. Peptides matching with $2 \mathrm{~S}$ albumin were found in all 22 CSPa and CSPw bands of glandless cottonseed protein, but only 9 of 19 bands of glanded samples (Fig. 6). Generally, the peptide strings (1-4 fragments) from glandless cottonseed protein were longer than the peptide sequence coverage of the glanded peptide fragments. In addition, the $2 \mathrm{~S}$ albumin peptides from glanded cottonseed samples were only observed in the C-terminus of the protein. Sharing the homology to potent antifungal proteins from cheeseweed seeds, these small $2 S$ albumin peptide fragments could potentially be used by cotton to form multiple antimicrobial molecules against a wide variety of pathogens ${ }^{37}$ during cottonseed germination.. 
(A) Glandless legumin A

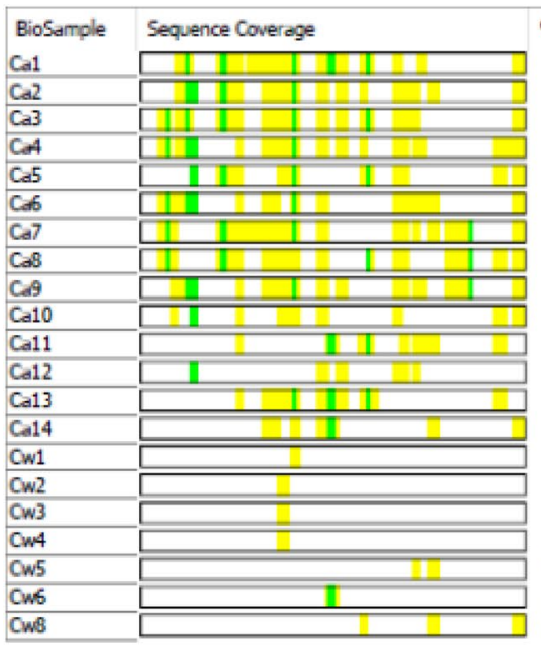

$\begin{array}{rrr}\% \text { Cov } & \text { \#Pep } & \% .5 p e c \\ 40 \% & 19 & 0.63 \% \\ 39 \% & 23 & 0.76 \% \\ 39 \% & 22 & 0.78 \% \\ 39 \% & 23 & 0.65 \% \\ 24 \% & 10 & 0.26 \% \\ 33 \% & 18 & 0.60 \% \\ 43 \% & 20 & 0.68 \% \\ 39 \% & 15 & 0.43 \% \\ 37 \% & 18 & 0.55 \% \\ 18 \% & 9 & 0.36 \% \\ 18 \% & 9 & 0.32 \% \\ 12 \% & 6 & 0.23 \% \\ 26 \% & 17 & 0.63 \% \\ 16 \% & 7 & 0.19 \% \\ 1.6 \% & 1 & 0.038 \% \\ 2.6 \% & 1 & 0.035 \% \\ 2.6 \% & 1 & 0.031 \% \\ 2.6 \% & 1 & 0.032 \% \\ 4.1 \% & 2 & 0.043 \% \\ 2.8 \% & 1 & 0.015 \% \\ 6.5 \% & 3 & 0.085 \%\end{array}$

\section{(C) Glanded legumin A}

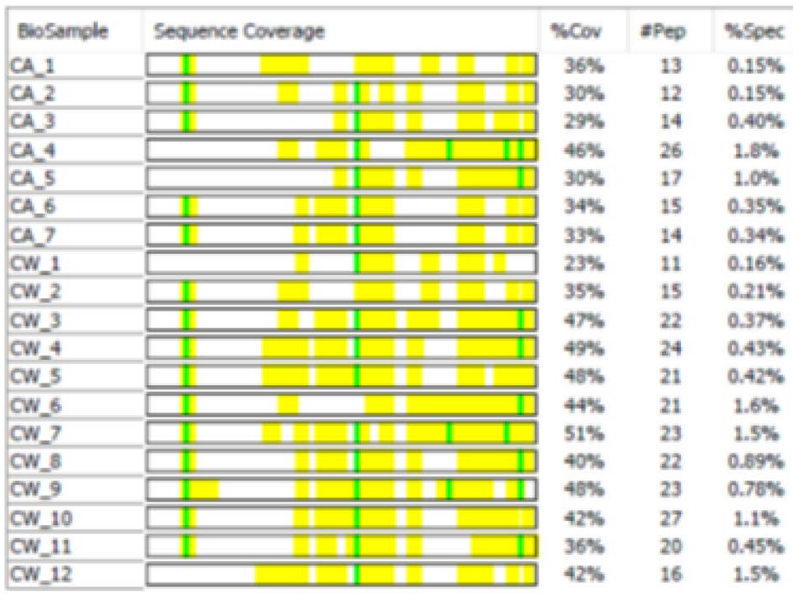

(B) Glandless legumin B

\begin{tabular}{|c|c|c|c|c|}
\hline BioSample & Sequence Coverage & $\% \mathrm{Cov}$ & \#Pep & \%5pec \\
\hline Ca1 & & $11 \%$ & 7 & $0.23 \%$ \\
\hline $\mathrm{CA} 2$ & 1 & $20 \%$ & 9 & $0.25 \%$ \\
\hline $\mathrm{Ca} 3$ & 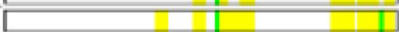 & $26 \%$ & 15 & $0.36 \%$ \\
\hline C.A 4 & \begin{tabular}{l|l}
-1 \\
\end{tabular} & $25 \%$ & 11 & $0.38 \%$ \\
\hline $\mathrm{Ca} 5$ & 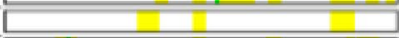 & $11 \%$ & 4 & $0.075 \%$ \\
\hline C.6 6 & 1 & $16 \%$ & 6 & $0.16 \%$ \\
\hline Ca7 & + & $25 \%$ & 11 & $0.31 \%$ \\
\hline $\operatorname{Cos}$ & 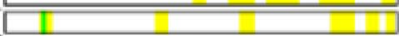 & $18 \%$ & 7 & $0.20 \%$ \\
\hline CA9 & \begin{tabular}{l|l|l|} 
& \\
\end{tabular} & $41 \%$ & 16 & $0.42 \%$ \\
\hline Ca10 & 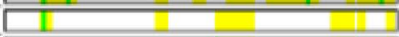 & $22 \%$ & 10 & $0.36 \%$ \\
\hline Ca11 & 1 & $15 \%$ & 8 & $0.30 \%$ \\
\hline Ca12 & - I & $18 \%$ & 10 & $0.30 \%$ \\
\hline Ca13 & + & $7.6 \%$ & 3 & $0.10 \%$ \\
\hline Ca14 & 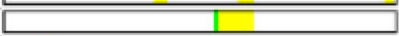 & $8.7 \%$ & 4 & $0.086 \%$ \\
\hline Qw1 & $\overline{1}$ & $3.1 \%$ & 1 & $0.019 \%$ \\
\hline Ow4 & 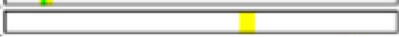 & $3.3 \%$ & 1 & $0.032 \%$ \\
\hline Cw5 & & $1.6 \%$ & 1 & $0.014 \%$ \\
\hline Cw6 & & $2.9 \%$ & 1 & $0.029 \%$ \\
\hline Cw7 & T & $8.7 \%$ & 4 & $0.19 \%$ \\
\hline Ow6 & 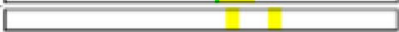 & $5.0 \%$ & 3 & $0.068 \%$ \\
\hline
\end{tabular}

\section{(D) Glanded legumin B}

\begin{tabular}{|c|c|c|c|c|}
\hline Biosample & Sequence Coverage & NCor & aPep & Wspec \\
\hline CA_1 & 1 & $33 \%$ & 13 & $0.17 \%$ \\
\hline CA 2 & 111 & $55 \%$ & 24 & $0.46 \%$ \\
\hline CA_3 & I I I & $45 \%$ & 24 & $2.4 \%$ \\
\hline C.4 & \begin{tabular}{|l|l|}
+10 \\
\end{tabular} & $64 \%$ & 35 & $1.7 \%$ \\
\hline CA.5 & 1 & $43 \%$ & 23 & $0.66 \%$ \\
\hline CA_6 & \begin{tabular}{|l|l|l|}
110 \\
\end{tabular} & $56 \%$ & 28 & $0.65 \%$ \\
\hline CA 7 & 101 & $53 \%$ & 34 & $1.6 \%$ \\
\hline$C_{-1}$ & \begin{tabular}{|l|l|l|l|l|l|l|} 
III & I \\
\end{tabular} & $40 \%$ & 17 & $0.21 \%$ \\
\hline$W_{2} 2$ & $\begin{array}{llll}1 & 1 & 1 \\
\end{array}$ & $64 \%$ & 28 & $0.58 \%$ \\
\hline $\mathrm{CW}_{3} 3$ & 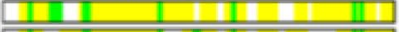 & $68 \%$ & 29 & $0.68 \%$ \\
\hline $\mathrm{CW}_{4} 4$ & \begin{tabular}{|l|l|l|l|l|l|} 
& \\
\end{tabular} & $61 \%$ & 31 & $0.66 \%$ \\
\hline $\mathrm{CW}_{-} \mathrm{s}$ & $11 \mathrm{II}$ & $66 \%$ & 30 & $2.3 \%$ \\
\hline CW_6 & \begin{tabular}{|l|l|}
11 & \\
\end{tabular} & $75 \%$ & 38 & $2.1 \%$ \\
\hline CW. 7 & \begin{tabular}{|l|l|}
1 & 1 \\
\end{tabular} & $57 \%$ & 30 & $1.4 \%$ \\
\hline $\mathrm{CW}_{-} \mathrm{B}$ & \begin{tabular}{|l|l}
11 \\
\end{tabular} & $51 \%$ & 27 & $0.88 \%$ \\
\hline CW 9 & \begin{tabular}{|l|l|}
111 \\
\end{tabular} & $55 \%$ & 30 & $1.1 \%$ \\
\hline CW_10 & $\square$ & $44 \%$ & 28 & $1.6 \%$ \\
\hline CW_11 & \begin{tabular}{|l|l|} 
& 111 \\
\end{tabular} & $50 \%$ & 38 & $3.0 \%$ \\
\hline$C W_{-12}$ & \begin{tabular}{|l|l|l|}
+1 & -1 \\
\end{tabular} & $41 \%$ & 23 & $0.93 \%$ \\
\hline
\end{tabular}

Figure 4. Sequence coverage of peptide fragments of legumins in glandless and glanded samples. The identified peptides are highlighted in yellow and the post-translational modification in green. The columns "\% Cov1", "\# Pep" and "\% Spec" show the \% of the identified fragment strings in the full length of the protein sequence, number of peptide fragments, and their relative abundance in each band, respectively. Data of glanded sample are from the work described in $\mathrm{He}$ et $\mathrm{al} .{ }^{4}$.

By the way, more oxidation and carbamidomethyl (CAM) modification were observed with the $2 \mathrm{~S}$ albumin fragments in glandless bands (up to 9 modifications in glandless sample vs 6 or less modifications in glanded sample shown in green in Fig. 6. However, CAM was a deliberate post-translational modification introduced to cysteine residues by reacting with iodoacetamide during sample preparation so that it was not indicative of a plant directed effort. The oxidation modifications could also part of sample preparation and not likely to be plant directed.

There were two types of lipid body-related oleosins with molecular weights of $16.4 \mathrm{kDa}$ and $18.2 \mathrm{kDa}$ in glandless samples, but only one type in glanded cottonseed protein (Fig. 6). They were relatively less abundant (not in the top 10), and only found in a few SDS-PAGE bands. The fragments from the $16.4 \mathrm{kDa}$ oleosin were from the C-terminus of the protein in both glandless and glanded cottonseed samples even though the observed peptides were different. In contrast, 5 of 6 bands from the $\mathrm{N}$-terminus of the $18.2 \mathrm{kDa}$ oleosin were observed. Tzen et al. ${ }^{38}$ reported that the difference between maize $16 \mathrm{kDa}$ and $18 \mathrm{kDa}$ olesin proteins can be explained by an extra amino acid sequence of $2 \mathrm{kDa}$ at the $\mathrm{C}$-terminus of the $18 \mathrm{kDa}$. Santiago et al. ${ }^{39}$ found that coconut oleosin was composed of various isoforms with molecular weights of 48.78, 35.12, 32.39, 28.15, 22.06, and $16.13 \mathrm{kDa}$ from SDS-PAGE analysis. Similarly, the possible presence of multiple isoforms of cottonseed oleosin can be seen in Fig. $5 \mathrm{~B}$ and D. The olesin protein in glandless cottonseed was dominated by the $18.4 \mathrm{kDa}$ form, while the majority, if not all, of glanded oleosin was the $16.2 \mathrm{kDa}$ form. Oleosins mainly act as oil body structural proteins and are important for the biogenesis, stability, and dynamics of the organelle ${ }^{40}$. Further research on the two oleosins in the two types of cottonseeds may shed new light into their roles in metabolism and cotton development. 


\section{(A) Glandless Vicilin-like antimicrobial peptides 2-1}

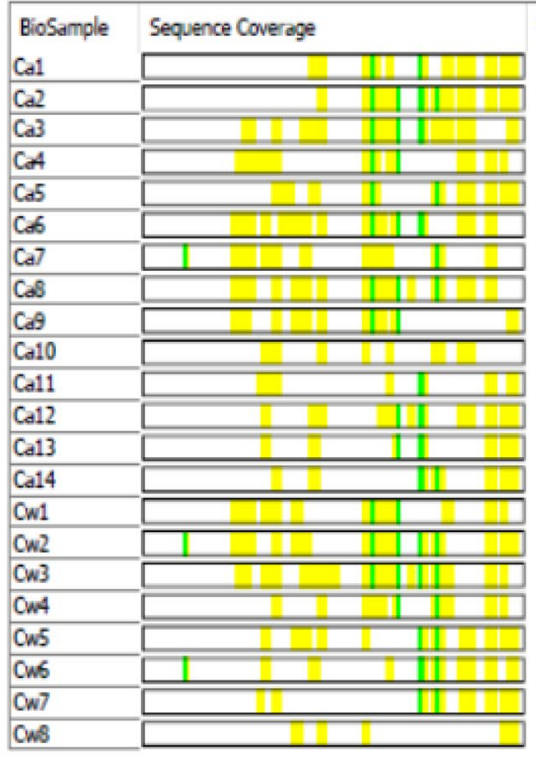

(B) Glandless Vicilin-like antimicrobial peptides $2-2$

\begin{tabular}{|c|c|c|c|c|}
\hline BioSample & Sequence Coverage & $9 \mathrm{Cov}$ & \#Pep & \%Spec \\
\hline $\mathrm{Ca} 1$ & & $4.1 \%$ & 2 & $0.035 \%$ \\
\hline $\mathrm{Ca} 2$ & & $8.2 \%$ & 4 & $0.099 \%$ \\
\hline $\mathrm{CA3}$ & & $6.7 \%$ & 3 & $0.086 \%$ \\
\hline CAA & 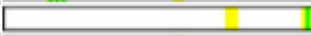 & $4.1 \%$ & 2 & $0.050 \%$ \\
\hline $\mathrm{Ca} 7$ & & $5.5 \%$ & 2 & $0.046 \%$ \\
\hline CAS & - & $4.5 \%$ & 2 & $0.066 \%$ \\
\hline $\mathrm{CAs}$ & & $2.4 \%$ & 1 & $0.016 \%$ \\
\hline Ca10 & & $7.1 \%$ & 2 & $0.056 \%$ \\
\hline Call & & $2.4 \%$ & 1 & $0.020 \%$ \\
\hline Ca12 & $\|$ & $17 \%$ & 7 & $0.23 \%$ \\
\hline Ca13 & $T$ & $2.4 \%$ & 1 & $0.017 \%$ \\
\hline Ca14 & $=$ & $8.2 \%$ & 4 & $0.10 \%$ \\
\hline Ow1 & $=$ & $20 \%$ & 7 & $0.21 \%$ \\
\hline $\mathrm{Cw2}$ & 11 & $20 \%$ & 9 & $0.39 \%$ \\
\hline Cw3 & 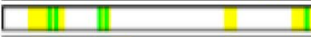 & $25 \%$ & 12 & $0.43 \%$ \\
\hline Ont & 11 & $28 \%$ & 10 & $0.37 \%$ \\
\hline CW5 & & $9.2 \%$ & 4 & $0.13 \%$ \\
\hline On6 & = & $8.4 \%$ & 3 & $0.044 \%$ \\
\hline Cw7 & & $7.8 \%$ & 4 & $0.12 \%$ \\
\hline Cus & III & $7.1 \%$ & 3 & $0.065 \%$ \\
\hline
\end{tabular}

(C) Glanded Vicilin-like antimicrobial peptides 2-1

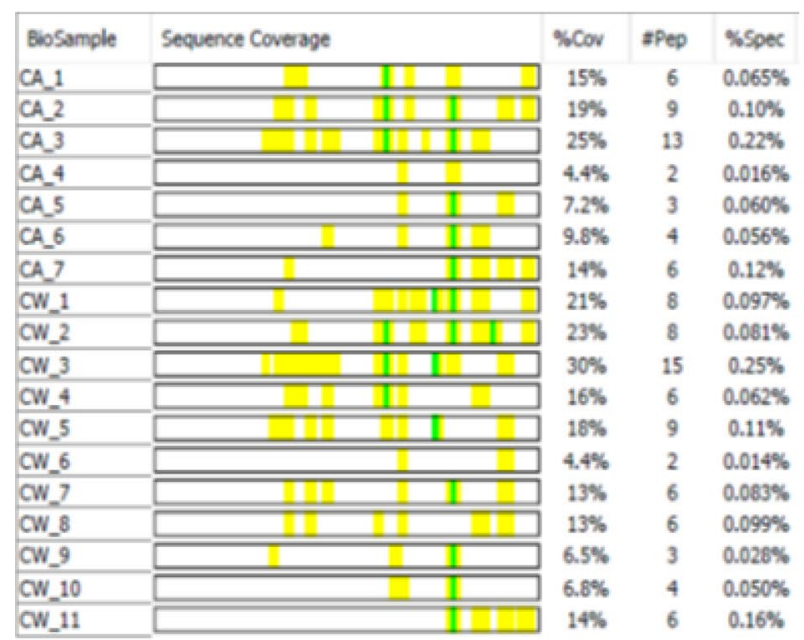

(D) Glanded Vicilin-like antimicrobial peptides 2-2

\begin{tabular}{|c|c|c|c|c|}
\hline BioSample & Sequence Coverage & $\% \mathrm{Cov}$ & sPep & \%Sper \\
\hline $\mathrm{CA}_{3}$ & 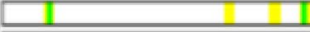 & $7.3 \%$ & 4 & $0.047 \%$ \\
\hline CA_4 & & $0.00 \%$ & 0 & $0.00 \%$ \\
\hline CA_S & & $2.6 \%$ & 3 & $0.026 \%$ \\
\hline CW_1 & & $0.00 \%$ & 0 & $0.00 \%$ \\
\hline$C W_{-} 4$ & $=$ & $4.3 \%$ & 1 & $0.015 \%$ \\
\hline CW_6 & ב & $4.3 \%$ & 1 & $0.0070 \% \times$ \\
\hline $\mathrm{CW}_{2} 7$ & 1 & $4.1 \%$ & 1 & $0.0092 \%$ \\
\hline CW_9 & II & $2.4 \%$ & 1 & $0.018 \%$ \\
\hline CW_10 & & $3.1 \%$ & 1 & $0.010 \%$ \\
\hline
\end{tabular}

Figure 5. Sequence coverage of peptide fragments of vicilin-like antimicrobial peptides in glandless and glanded samples. The identified peptides are highlighted in yellow and the post-translational modification in green. The columns "\% Cov1", "\# Pep" and "\% Spec" show the \% of the identified fragment strings in the full length of the protein sequence, number of peptide fragments, and their relative abundance in each band, respectively. Data of glanded sample are from the work described in $\mathrm{He}$ et al. ${ }^{4}$.

\section{Conclusions}

This work reported the polypeptide profile of water and alkali soluble protein fractions of glandless cottonseed. SDS-Gel electrophoresis separated CSPw and CSPa to 8 and 14 dominant protein bands, respectively. LC-ESI-MS/MS of the 22 protein bands identified a total of 5115 unique peptides that were matched to 336 proteins. While the majority of peptides were matched to vicilin and legumin storage proteins, peptides from other functional and uncharacterized proteins were also detected. Compared to the polypeptide profile of the glanded cottonseed protein in literature, glandless cottonseed protein possessed relatively lower levels (abundance) and types (diversity) of legumin isoforms, but higher levels and more fragments of vicilin-like antimicrobial peptides. This work enriched the fundamental knowledge of glandless cottonseed protein composition, thus being 
(A) Glandless $2 \mathrm{~S}$ albumin storage protein

\begin{tabular}{|l|l|}
\hline BioSample & Sequence Coverage \\
Ca1 & \\
\hline Ca2 & \\
\hline Ca3 & \\
\hline Ca4 & \\
\hline Ca5 & \\
\hline Ca6 & \\
\hline Ca7 & \\
\hline Ca6 & \\
\hline Ca9 & \\
\hline Ca10 & \\
\hline Ca11 & \\
\hline Ca12 & \\
\hline Ca13 & \\
\hline Ca14 & \\
\hline Cw1 & \\
\hline Cw2 & \\
\hline Ow3 & \\
\hline Ow4 & \\
\hline Cw5 & \\
\hline Cw6 & \\
\hline Cw7 & \\
\hline Cw6 & \\
\hline
\end{tabular}

\begin{tabular}{|c|cc}
\hline $6 C$ Cov & \#Pep & $\%$ \%spec \\
$8.6 \%$ & 1 & $0.017 \%$ \\
$21 \%$ & 2 & $0.099 \%$ \\
$21 \%$ & 2 & $0.086 \%$ \\
$31 \%$ & 4 & $0.25 \%$ \\
$21 \%$ & 2 & $0.075 \%$ \\
$21 \%$ & 2 & $0.029 \%$ \\
$21 \%$ & 2 & $0.15 \%$ \\
$21 \%$ & 2 & $0.049 \%$ \\
$12 \%$ & 1 & $0.048 \%$ \\
$31 \%$ & 4 & $0.36 \%$ \\
$12 \%$ & 1 & $0.060 \%$ \\
$31 \%$ & 4 & $0.25 \%$ \\
$31 \%$ & 4 & $0.35 \%$ \\
$31 \%$ & 4 & $0.65 \%$ \\
$21 \%$ & 2 & $0.094 \%$ \\
$21 \%$ & 2 & $0.071 \%$ \\
$21 \%$ & 2 & $0.093 \%$ \\
$27 \%$ & 3 & $0.29 \%$ \\
$8.6 \%$ & 1 & $0.058 \%$ \\
$21 \%$ & 2 & $0.12 \%$ \\
$25 \%$ & 3 & $0.33 \%$ \\
$21 \%$ & 2 & $0.26 \%$
\end{tabular}

\section{(C) Glanded 2S albumin storage protein}

\begin{tabular}{|c|c|c|c|c|}
\hline BioSample & Sequence Coverage & \%Cov & *Pep & \%Spec \\
\hline Ca_2 & & $8.6 \%$ & 1 & $0.0069 \%:$ \\
\hline CA_3 & IIII & $12 \%$ & 1 & $0.0094 \%$ \\
\hline CA_4 & & $8.6 \%$ & 1 & $0.016 \%$ \\
\hline CA_5 & $\overline{\mathrm{I}}$ & $23 \%$ & 2 & $0.017 \%$ \\
\hline CA_7 & 111 & $21 \%$ & 2 & $0.021 \%$ \\
\hline $\mathrm{CW}_{-} 3$ & $\bar{I}$ & $13 \%$ & 1 & $0.0073 \%$ \\
\hline CW_4 & & $12 \%$ & 1 & $0.0077 \%$ \\
\hline CW_B & 1111 & $25 \%$ & 3 & $0.039 \%$ \\
\hline CW_12 & III & $12 \%$ & 1 & $0.090 \%$ \\
\hline
\end{tabular}

(B1) Glandless Oleosin 16.4 kDa

\begin{tabular}{|l|l|c|cc|}
\hline BioSample & Sequence Coverage & \%Cov & \#Pep & $\%$ \%pec \\
Ca4 & $0.00 \%$ & 0 & $0.00 \%$ \\
\hline OW3 & $7.1 \%$ & 1 & $0.015 \%$ \\
\hline OW6 & $0.00 \%$ & 0 & $0.00 \%$ \\
\hline OW7 & $7.1 \%$ & 1 & $0.030 \%$ \\
\hline On6 & $7.1 \%$ & 2 & $0.068 \%$ \\
\hline
\end{tabular}

\section{(B2) Glandless Oleosin 18.2 kDa}

\begin{tabular}{|l|l|rrr|}
\hline BioSample & Sequence Coverage & \%Cov & \#Pep & $\% 5$ Spec \\
Ca11 & $8.9 \%$ & 1 & $0.040 \%$ \\
\hline Ca12 & $21 \%$ & 3 & $0.088 \%$ \\
\hline Cw3 & $8.9 \%$ & 1 & $0.015 \%$ \\
\hline Cw4 & $7.7 \%$ & 1 & $0.016 \%$ \\
\hline Cw6 & $8.9 \%$ & 1 & $0.015 \%$ \\
\hline Cw7 & $14 \%$ & 3 & $0.060 \%$ \\
\hline Cw6 & $12 \%$ & 2 & $0.085 \%$ \\
\hline
\end{tabular}

\section{(D) Glanded Oleosin 16.4 kDa}

\begin{tabular}{|l|l|rrr|}
\hline BlioSample & \multicolumn{1}{|c|}{ Sequence Coverage } & NCov & iPep & NSpec \\
CA_6 & $23 \%$ & 4 & $0.056 \%$ \\
CA.7 & $7.8 \%$ & 1 & $0.021 \%$ \\
\hline CW_8 & $7.8 \%$ & 1 & $0.0099 \%$ \\
\hline CW_9 & $7.8 \%$ & 1 & $0.0092 \%$ \\
\hline CW_10 & $7.6 \%$ & 1 & $0.020 \%$ \\
\hline
\end{tabular}

Figure 6. Sequence coverage of peptide fragments of $2 S$ albumin and oleosin in glandless and glanded samples. The identified peptides are highlighted in yellow and the post-translational modification in green. The columns "\% Cov1", "\# Pep" and "\% Spec" show the \% of the identified fragment strings in the full length of the protein sequence, number of peptide fragments, and their relative abundance in each band, respectively. Data of glanded sample are from the work described in $\mathrm{He}^{4}$.

helpful in better understanding the functional and physicochemical properties of glandless cottonseed protein for food and feed applications.

\section{Materials and methods}

Cottonseed protein products. Defatted cottonseed meal from glandless variety "NuMex 15 GLS" was provided by Cotton, Inc. (Cary, NC, USA) ${ }^{41}$. A two-step extraction and precipitation procedure was applied to obtained the water soluble $(\mathrm{CSPw})$ and alkali soluble (CSPa) glandless cottonseed protein fractions from the defatted meal ${ }^{24,42}$. Briefly, the water- $(\mathrm{CSP})$ and alkali-(CSPa) soluble protein fractions in the defatted cottonseed meal were sequentially extracted by water (naturally around $\mathrm{pH} 7.0$ ) and $0.015 \mathrm{M} \mathrm{NaOH}$, and then precipitated at $\mathrm{pH} 4.0$ and 7.0, respectively, by $\mathrm{pH}$ adjustment with $1 \mathrm{M} \mathrm{HCl.}$ Both fractions were freeze-dried and kept at $-20^{\circ} \mathrm{C}$ until use. It should be aware that the sequential extraction of the cottonseed protein was a relative measure of different fractions in defatted meal. This is because, prior to defatting, cottonseeds, like other oilseeds, are generally subjected to a "cooking" process which might make some protein denatured and aggregated, affecting their relative solubility ${ }^{43,44}$. The protein contents of CSPw and CSPa were about $79 \%$ and $97 \%$, respectively, converted from the total $\mathrm{N}$ content using $\mathrm{d}$ using a conversion factor of $5.5^{45}$. To detect the presence of protein disulfide bonds dithiothreitol (DTT, Sigma-Aldrich, St. Louis, MO, USA) at $4 \mathrm{mM}$ final concentration was added to CSPw and CSPa samples $(2 \mu \mathrm{g})$ in $50 \mathrm{mM}$ ammonium bicarbonate buffer $(\mathrm{pH} 8.0)$ at $37^{\circ} \mathrm{C}$ for $15 \mathrm{~min}$. Prior to trypsin digestion and LC-MS/MS analysis, reduced protein samples were alkylated in the dark with $15 \mathrm{mM}$ iodoacetamide in $50 \mathrm{mM}$ ammonium bicarbonate buffer ( $\mathrm{pH} 8.0$ ) for $30 \mathrm{~min}$ at room temperature. Iodoacetamide was then quenched by the addition of $4 \mathrm{mM}$ DTT.

Sodium dodecyl sulphate-polyacrylamide gel electrophoresis (SDS-PAGE). CSPw and CSPa samples $(2 \mu \mathrm{g} / \mathrm{lane})$ were solubilized in 4 X NuPAGE LDS Sample Buffer (pH 8.5) (ThermoFisher Scientific, USA), with or without DTT as above, and heated at $55^{\circ} \mathrm{C}$ for $5 \mathrm{~min}$. Following a brief centrifugation step to 
remove particulates, samples were electrophoresed for $90 \mathrm{~min}$ at constant voltage (125 V) on Novex 10-20\% Tricine Mini Protein Gels (ThermoFisher Scientific, USA) using an XCell SureLock Mini-Cell (ThermoFisher Scientific, USA) apparatus with prestained Precision Plus molecular weight standards (Bio-Rad, USA) ${ }^{46}$. Following electrophoresis, gels were rinsed and stained with SimplyBlue SafeStain (ThermoFisher Scientific, USA) according to manufacturer's instructions. Gels were visualized and protein band intensities were quantified using the $680 \mathrm{~nm}$ channel on a Li-Cor Odyssey infrared scanner and Image Studio software (LI-COR Biosciences, USA). The relative band intensity of a band was calculated by the percentage of that specific band intensity out of the sum of all band intensity values, and used to represent the relative protein content of that band in the total protein mass).

Liquid chromatography-electrospray ionization-tandem spectrometry (LC-ESI-MS/ MS). Another set of CSPw and CSPa samples (10 $\mu \mathrm{g} /$ lane for six lanes each sample) were subjected to SDSPAGE under the same conditions as described above. Individual bands excised from the multiple SDS-PAGE lanes were pooled and subjected to in-gel trypsin digestion ${ }^{42}$. The fragments in the digestion samples were analyzed by LC-ESI-MS/MS by UAB Mass Spectrometry/Proteomics Shared Facility (University of Alabama at Birmingham, Birmingham, Alabama, USA). The data were acquired with Bruker UltraFlex III MALDI ToF/ ToF. The tandem mass spectral data generated were processed with SEQUEST and searched by Mascot against protein databases. The quantitative values of the normalized total ion current (TIC) of the peptide MS fragments were used as a relative measurement of the observed peptide in the gel bands. Scaffold (version Scaffold_4.11.0, Proteome Software Inc., Portland, OR) was used to validate MS/MS based peptide and protein identifications. The molecular function of individual proteins was searched via UniPro (https://www.uniprot.org/uniprot/) and/ or Conserved Domains in NCBI-BLASTp (https://blast.ncbi.nlm.nih.gov/Blast.cgi). In addition to the specific functions, per the online search results, these proteins were grouped into 11 categories (Gene Ontology terms) for general identification.

Experimental design and statistical analysis. Relative abundance of the major protein fractions separated by SDS-PAGE were calculated as their band intensities relative to the total band intensity of each lane. The lanes were measured and data were presented as the average with standard deviation $(n=3)$.

Same gel bands of six SDS-PAGE lanes were pooled as one sample for LC-ESI-MS/MS. For MS data treatments, peptide identifications were accepted if they could be established at greater than $80.0 \%$ probability by the Peptide Prophet algorithm with Scaffold delta-mass correction. Protein identifications were accepted if they could be established at greater than $99.0 \%$ probability and contained at least 2 identified peptides. Protein probabilities were assigned by the Protein Prophet algorithm ${ }^{47}$. Proteins that contained similar peptides and could not be differentiated based on MS/MS analysis alone were grouped to satisfy the principles of parsimony.

Received: 8 December 2020; Accepted: 12 April 2021

Published online: 28 April 2021

\section{References}

1. Cheng, H. N., He, Z., Ford, C., Wyckoff, W. \& Wu, Q. A review of cottonseed protein chemistry and non-food applications. Sustain. Chem. 1, 256-274 (2020).

2. Zubair, M. et al. A combinational approach of enhanced methanol production and double Bt genes for broad spectrum insect resistance in transgenic cotton. Mol. Biotechnol. 61, 663-673 (2019).

3. Rojo-Gutiérrez, E., Buenrostro-Figueroa, J., López-Martínez, L., Sepúlveda, D. \& Baeza-Jiménez, R. Valorisation of Agro-industrial Residues-Volume II: Non-Biological Approaches 63-82 (Springer, 2020).

4. He, Z., Zhang, D. \& Cao, H. Protein profiling of water and alkali soluble cottonseed protein isolates. Sci. Rep. 8, 9306. https://doi. org/10.1038/s41598-41018-27671-z (2018).

5. Singh, A. \& Kaur, A. Comparative studies on seed protein characteristics in eight lines of two Gossypium species. J. Cotton Res. 2, 6. https://doi.org/10.1186/s42397-42019-40024-42393 (2019).

6. Li, J. et al. Assessment and application of phosphorus/calcium-cottonseed protein adhesive for plywood production. J. Clean. Prod. 229, 454-462 (2019).

7. Cheng, H. N., Ford, C. V. \& He, Z. Evaluation of polyblends of cottonseed protein and polycaprolactone plasticized by cottonseed oil. Int. J. Polymer Anal. Character. 24, 389-398 (2019).

8. Cheng, H. N., Ford, C. V., Dowd, M. K. \& He, Z. Soy and cottonseed protein blends as wood adhesives. Ind. Crop. Prod. 85, 324-330 (2016).

9. Liu, M., Wang, Y., Wu, Y., He, Z. \& Wan, H. “Greener” adhesives composed of urea-formaldehyde resin and cottonseed meal for wood-based composites. J. Clean. Prod. 187, 361-371 (2018).

10. He, Z., Cheng, H. N. \& Nam, S. Comparison of the wood bonding performance of water-and alkali-soluble cottonseed protein fractions. J. Adhes. Sci. Technol. https://doi.org/10.1080/01694243.2020.1850612,1-18 (2021).

11. de Oliveira Filho, J. G. et al. Active food packaging: Alginate films with cottonseed protein hydrolysates. Food Hydrocolloids $\mathbf{9 2}$, 267-275 (2019).

12. Yue, H. et al. On the improvement of properties of bioplastic composites derived from wasted cottonseed protein by rational cross-linking and natural fiber reinforcement. Green Chem. https://doi.org/10.1039/D0GC03245J (2020).

13. Song, W. et al. Antioxidant and antibacterial activity and in vitro digestion stability of cottonseed protein hydrolysates. $L W T$ 118, 108724 (2020).

14. He, Z., Zhang, D. \& Olanya, O. M. Antioxidant activities of the water-soluble fractions of glandless and glanded cottonseed protein. Food Chem. 325, 126907 (2020).

15. Mohammadrezaei, M., Navidshad, B., Gheisari, A. \& Toghyani, M. Cottonseed meal bioactive peptides as an alternative to antibiotic growth promoters in broiler chicks. Int. J. Peptide Res. Therap. 1-12 (2020).

16. Rathore, K. S. et al. Ultra-low gossypol cottonseed: Selective gene silencing opens up a vast resource of plant-based protein to improve human nutrition. Crit. Rev. Plant Sci. 39, 1-29 (2020).

17. Zhang, J. et al. Registration of 'NuMex COT 15 GLS' glandless cotton. J. Plant Regist. 10, 223-227 (2016). 
18. Cao, H., Sethumadhavan, K. \& Bland, J. M. Isolation of cottonseed extracts that affect human cancer cell growth. Sci. Rep. 8, 1-12 (2018).

19. Cheng, H. N., Dowd, M. K. \& He, Z. Investigation of modified cottonseed protein adhesives for wood composites. Ind. Crop. Prod. 46, 399-403 (2013).

20. Cheng, H. N., Wyckoff, W., Dowd, M. K. \& He, Z. Evaluation of adhesion properties of blends of cottonseed protein and anionic water-soluble polymers. J. Adhes. Sci. Technol. 33, 66-78 (2019).

21. He, Z., Cheng, H. N., Chapital, D. C. \& Dowd, M. K. Sequential fractionation of cottonseed meal to improve its wood adhesive properties. J. Am. Oil Chem. Soc. 91, 151-158 (2014).

22. Cao, H. \& Sethumadhavan, K. Cottonseed extracts and gossypol regulate diacylglycerol acyltransferase gene expression in mouse macrophages. J. Agric. Food Chem. 66, 6022-6030 (2018).

23. Delgado, E. et al. Characterization of soluble glandless cottonseed meal proteins based on electrophoresis, functional properties, and microscopic structure. J. Food Sci. 84, 2820-2830 (2019).

24. He, Z., Cao, H., Cheng, H. N., Zou, H. \& Hunt, J. F. Effects of vigorous blending on yield and quality of protein isolates extracted from cottonseed and soy flours. Mod. Appl. Sci. 7(10), 79-88 (2013).

25. Ma, M. et al. Physicochemical and functional properties of protein isolate obtained from cottonseed meal. Food Chem. 240, 856-862 (2018).

26. Conkerton, E. J. \& Frampton, V. L. Reaction of gossypol with free $\epsilon$-amino groups of lysine in proteins. Arch. Biochem. Biophys. 81, 130-134 (1959).

27. Dowd, M. K. \& Hojilla-Evangelista, M. P. Preparation and characterization of protein isolate from glandless and glanded cottonseed. ACS Symp. Ser. 1144, 343-357 (2013).

28. Goyal, R. K. \& Mattoo, A. K. Multitasking antimicrobial peptides in plant development and host defense against biotic/abiotic stress. Plant Sci. 228, 135-149 (2014).

29. Hu, G. et al. Genomically biased accumulation of seed storage proteins in allopolyploid cotton. Genetics 189, 1103-1115 (2011).

30. Shutov, A. D., Kakhovskaya, I. A., Braun, H., Baumlein, H. \& Muntz, K. Legumin-like and vicilin-like seed storage proteins: Evidence for a common single-domain ancestral gene. J. Mol. Evolut. 41, 1057-1069 (1995).

31. Vieira Bard, G.C. et al. Vicilin-like peptides from Capsicum baccatum L. seeds are $\alpha$-amylase inhibitors and exhibit antifungal activity against important yeasts in medical mycology. Peptide Sci. 102, 335-343 (2014).

32. Xie, Z., Saha, N. \& Chlan, C. Antimicrobial activity of a cys-rich peptide derived from a Centrosema virginianum vicilin. Am. J. Plant Sci. 7, 92-107 (2016).

33. Gao, W. et al. The gland localized CGP1 controls gland pigmentation and gossypol accumulation in cotton. Plant Biotechnol. J. 18, $1573(2020)$

34. Chung, R.P.-T., Neumann, G. M. \& Polya, G. M. Purification and characterization of basic proteins with in vitro antifungal activity from seeds of cotton, Gossypium hirsutum. Plant Sci. 127, 1-16 (1997).

35. Swiatkiewicz, S., Arczewska-Wlosek, A. \& Jozefia, D. The use of cottonseed meal as a protein source for poultry: An updated review. World Poultry Sci. J. 72, 473-484 (2016).

36. Abdallh, M. et al. Energy and protein utilisation by broiler chickens fed diets containing cottonseed meal and supplemented with a composite enzyme product. Br. Poultry Sci. 103, 5102-5117 (2020).

37. Wang, X., Bunkers, G. J., Walters, M. R. \& Thoma, R. S. Purification and characterization of three antifungal proteins from cheeseweed (Malva parviflora). Biochem. Biophys. Res. Commun. 282, 1224-1228 (2001).

38. Tzen, J. T., Lai, Y.-K., Chan, K.-L. \& Huang, A. H. Oleosin isoforms of high and low molecular weights are present in the oil bodies of diverse seed species. Plant Physiol. 94, 1282-1289 (1990).

39. Santiago, M.R. \& Devanadera, M.K.P. Microencapsulation of Pediococcus spp. with coconut oil bodies and oleosin for improved viability and enhanced targeted delivery in the gastrointestinal tract. Philippine Agric. Sci. 99 (2016).

40. Shao, Q., Liu, X., Su, T., Wang, P. \& Ma, C. New insights into the role of seed oil body proteins in metabolism and plant development. Front. Plant Sci. 10, 1568 (2019).

41. He, Z., Zhang, H. \& Olk, D. C. Chemical composition of defatted cottonseed and soy meal products. PLoS ONE 10(6), e0129933 (2015).

42. He, Z., Uchimiya, M. \& Cao, H. Intrinsic fluorescence excitation-emission matrix spectral features of cottonseed protein fractions and the effects of denaturants. J. Am. Oil Chem. Soc. 91, 1489-1497 (2014).

43. Chen, N., Zhao, M., Chassenieux, C. \& Nicolai, T. Thermal aggregation and gelation of soy globulin at neutral pH. Food Hydrocolloids 61, 740-746 (2016).

44. Dowd, M.K. Cotton. 2nd edn. In Agronomy Monograph, Vol. 57. (eds. D.D. Fang \& R.G. Percy) 745-781 (ASA, CSSA, and SSSA, 2015).

45. Ezeagu, I., Petzke, J., Metges, C., Akinsoyinu, A. \& Ologhobo, A. Seed protein contents and nitrogen-to-protein conversion factors for some uncultivated tropical plant seeds. Food Chem. 78, 105-109 (2002).

46. Mattison, C. P., Grimm, C. C. \& Wasserman, R. L. In vitro digestion of soluble cashew proteins and characterization of surviving IgE-reactive peptides. Mol. Nutr. Food Res. 58, 884-893 (2014).

47. Nesvizhskii, A. I., Keller, A., Kolker, E. \& Aebersold, R. A statistical model for identifying proteins by tandem mass spectrometry. Anal. Chem. 75, 4646-4658 (2003).

\section{Acknowledgements}

We thank Kyoko Kojima and Brandon Young (University of Alabama at Birmingham CCC MS \& Proteomics Shared Facility) for help on liquid chromatography-electrospray ionization-tandem mass spectrometric analysis and protein identifications. Mention of trade names or commercial products in this publication is solely for the purpose of providing specific information and does not imply recommendation or endorsement by the U.S. Department of Agriculture. USDA is an equal opportunity provider and employer.

\section{Author contributions}

Conceived and designed the experiments: Z.H. Performed the experiments: Z.H., C.P.M., D.Z., C.G. Analyzed the data: Z.H., C.P.M., D.Z. Wrote the manuscript: Z.H. Manuscript editing: Z.H., C.P.M. All authors reviewed the manuscript.

\section{Competing interests}

The authors declare no competing interests. 


\section{Additional information}

Supplementary Information The online version contains supplementary material available at https://doi.org/ 10.1038/s41598-021-88527-7.

Correspondence and requests for materials should be addressed to Z.H.

Reprints and permissions information is available at www.nature.com/reprints.

Publisher's note Springer Nature remains neutral with regard to jurisdictional claims in published maps and institutional affiliations.

(c) (i) Open Access This article is licensed under a Creative Commons Attribution 4.0 International License, which permits use, sharing, adaptation, distribution and reproduction in any medium or format, as long as you give appropriate credit to the original author(s) and the source, provide a link to the Creative Commons licence, and indicate if changes were made. The images or other third party material in this article are included in the article's Creative Commons licence, unless indicated otherwise in a credit line to the material. If material is not included in the article's Creative Commons licence and your intended use is not permitted by statutory regulation or exceeds the permitted use, you will need to obtain permission directly from the copyright holder. To view a copy of this licence, visit http://creativecommons.org/licenses/by/4.0/.

This is a U.S. Government work and not under copyright protection in the US; foreign copyright protection may apply 2021 